\title{
Functionalized Ormosil Scaffolds Processed by Direct Laser Polymerization for Application in Tissue Engineering
}

Matei, A.; Schou, Jørgen; Canulescu, Stela; Zamfirescu, M.; Albu, C.; Mitu, B.; Buruiana, E. C.; Buruiana, T.; Mustaciosu, C.; Petcu, I.

Total number of authors:

11

Publication date:

2012

Link back to DTU Orbit

Citation (APA):

Matei, A., Schou, J., Canulescu, S., Zamfirescu, M., Albu, C., Mitu, B., Buruiana, E. C., Buruiana, T., Mustaciosu, C., Petcu, I., \& Dinescu, M. (2012). Functionalized Ormosil Scaffolds Processed by Direct Laser Polymerization for Application in Tissue Engineering. Abstract from E-MRS 2012 Spring Meeting, Strasbourg, France.

\section{General rights}

Copyright and moral rights for the publications made accessible in the public portal are retained by the authors and/or other copyright owners and it is a condition of accessing publications that users recognise and abide by the legal requirements associated with these rights.

- Users may download and print one copy of any publication from the public portal for the purpose of private study or research.

- You may not further distribute the material or use it for any profit-making activity or commercial gain

- You may freely distribute the URL identifying the publication in the public portal 


\title{
Functionalized Ormosil Scaffolds Processed by Direct Laser Polymerization for
}

\section{Application in Tissue Engineering}

\author{
A. Matei ${ }^{1,2}$, J. Schou $^{3}$, S. Canulescu ${ }^{3}$, M. Zamfirescu ${ }^{2}$, C. Albu ${ }^{2}$, B. Mitu ${ }^{2}$, E.C. Buruiana ${ }^{1}$, T. \\ Buruiana $^{1}$, C. Mustaciosu ${ }^{4}$, I. Petcu ${ }^{4}$, M. Dinescu ${ }^{2}$ \\ ${ }^{1}$ Petru Poni Institute of Macromolecular Chemistry, Grigore Ghica Voda 41A, 6600 Iasi, Romania \\ ${ }^{2}$ National Institute for Lasers, Plasma and Radiation Physics, Atomistilor 409, 77125 Bucharest- \\ Magurele, Romania \\ ${ }^{3}$ DTU Fotonik, Risø Campus, Technical University of Denmark, DK-4000 Roskilde, Denmark \\ ${ }^{4}$ Department of Environmental and Life Physics, National Institute for Physics and Nuclear \\ Engineering 'Horia Hulubei', Bucharest, Romania
}

\begin{abstract}
The N,N'-(methacryloyloxyethyl triehtoxy silyl propyl carbamoyl-oxyhexyl)-urea hybrid methacrylate for applications in tissue engineering was synthesized and afterwards polymerized by direct laser polymerization using femtosecond laser pulses with the aim of using it for further applications in tissue engineering. The as-obtained scaffolds were modified either by low pressure argon plasma treatment or by using two different proteins (lysozyme, fibrinogen). For improved adhesion, the proteins were deposited by matrix assisted pulsed laser evaporation. The functionalized structures were tested in L929 mouse fibroblasts culture and the cells morphology, proliferation, and attachment were analyzed.
\end{abstract}

